\title{
PENGGUNAAN MEDIA GAMBAR BERSERI \\ DALAM MENINGKATKAN KEMAMPUAN \\ MENULIS BAHASA JEPANG SISWA KELAS XII \\ PADA KELAS BAHASA MAN MODEL MANADO
}

\author{
Agustini Buchari \\ MAN Model Manado \\ agustinibuchari@yahoo.co.id
}

\begin{abstract}
Abstrak
Penelitian ini adalah penelitian tindakan kelas (PTK) yang bertujuan untuk (1) mengetahui sejauh mana kemampuan siswa kelas XII pada kelas Bahasa MAN Model Manado mengarang dalam bahasa tulis bahasa Jepang? dan (2) jika kemampuan siswa-siswa kelas XII pada kelas Bahasa MAN Model Manado menulis masih di bawah standar (kurang dari 60), apakah pemberian media melalui gambar berseri dan pemberian kata-kata kunci di bawah pengawasan dan pengamatan langsung oleh guru yang diadakan secara bervariasi, dapat meningkatkan kemampuan mereka menulis dalam bahasa Jepang? Hasil-hasil pemberian tindakan setiap siklus menunjukkan adanya peningkatan secara signifikan atau berarti, bukannya kebetulan. Hal itu tampak pada peningkatan kemampuan siswa kelas XII (kelas Bahasa) MAN Model Manado dari siklus ke siklus. Siklus pertama menunjukkan skor rata-rata 64,6 dari hasil tes awal 53,4. Pada siklus berikutnya, yaitu siklus kedua terjadi lagi peningkatan menjadi 77,4. Siklus ketiga 83,7 dan pada siklus yang keempat atau yang terakhir, skor rata-rata siswa meningkat menjadi 87,6. Berdasarkan kenyataan bahwa pemberian tugas menulis dengan menggunakan alat bantu atau media berupa gambar berseri yang disertai dengan kata-kata kunci efektif untuk meningkatkan kemampuan siswa menulis dalam bahasa tulis bahasa Jepang, maka disarankan pada para guru agar dalam latihan-latihan atau tugas-tugas menuis dalam pembelajaran bahasa yang diberikan kepada para siswa mestilah menggunakan lebih banyak alat bantu atau
\end{abstract}


media pembelajaran berupa gambar-gambar berseri yang disertai dengan kata-kata kunci.

\section{Kata Kunci: gambar berseri, menulis, bahasa Jepang.}

\section{A. Pendahuluan}

Dalam buku Petunjuk Teknis Pengembangan Silabus dan Contoh/Model Silabus Mata Pelajaran Bahasa Jepang disebutkan bahwa pembelajaran bahasa Jepang di SMA/MA merupakan pelajaran tingkat dasar awal yang pembelajarannya bersifat tematis. Pada standar kompetensi (SK) tersaji tema yang memandu pencapaian kompetensi dan penjabaran materi yang harus dikuasai siswa sedangkan pada kompetensi dasar (KD) tersaji kompetensi minimal yang diperoleh siswa setelah mempelajari bahasa Jepang per semester.

Juga disebutkan bahwa pembelajaran bahasa Jepang mencakup empat aspek yaitu, mendengarkan, berbicara, membaca, dan menulis. Ke empat aspek ini tidak dapat disajikan secara terpisah dalam pembelajarannya. Setiap aspek keterampilan kebahasaan saling mendukung untuk pencapaian kompetensi dasar. Untuk itu, dalam pembelajaran seyogyanya ke empat aspek ini diajarkan secara proposional dan berimbang. Setidaknya dalam pembelajaran bahasa membutuhkan minimal 2 aspek kebahasaan dalam rangka pencapaian kompetensi dasar.

Mengacu pada buku petunjuk teknis tersebut, dapat disebutkan bahwa pembelajaran bahasa Jepang sebagai bahasa Asing di SMA/MA merupakan proses yang kompleks yang memerlukan keterampilan dan kecakapan yang memadai dari seorang guru bahasa Jepang. hal ini sejalan dengan Brown (1980: 1-2) yang mengemukakan bahwa mempelajari bahasa kedua merupakan proses yang kompleks yang melibatkan sejumlah variable yang tak terbatas. Salah satu variabel yang pertama-tama dikemukakannya adalah variabel guru. Dalam hal ini, terdapat beberapa pertanyaan yang diajukannya sehubungan dengan masalah guru yaitu apa bahasa guru? Bagaimana pengalaman atau latihannya? Bagaimana pengetahuannya? Dan yang terpenting ditanyakannya adalah bagaimana murid dan guru berinteraksi sebagaimana insan manusia dalam komunitas bahasa. 
Selain faktor guru, faktor yang juga sangat penting adalah faktor metode dan media pembelajaran yang digunakan. Metode dan media sebagai komponen pembelajaran berdasarkan beberapa temuan penelitian menunjukkan bahwa kedua komponen itu memiliki peran yang sangat tinggi dalam memaksimalkan pencapaian tujjan pembelajaran termasuk dalam hal ini adalah pembelajaran bahasa Jepang.

Dalam kenyataannya proses pembelajaran bahasa Jepang sebagaimana pengalaman peneliti di Madrasah Aliyah Negeri Model Manado, masih ditemukan sejumlah kendala. Salah satu kendala yang masih umum ditemui adalah relatif masih rendahnya kemampuan menulis siswa. Berdasarkan hal itu, perlu dicari cara yang efektif dalam melatih siswa untuk menulis. Cara yang ditempuh ialah dengan jalan menggunakan media gambar berseri. Penggunaan media seperti ini lazim digunakan dalam berbagai bahan ajar. Maksudnya ialah agar materi yang disampaikan tidak terlalu abstrak. Dengan menggunakan media visual dalam bentuk gambar, maka para siswa diasumsikan dapat mengembangkan bahasanya melalui visualisasi cerita dalam bentuk gambar (picture).

Penggunaan gambar berseri seperti itu telah lama diperkenalkan oleh Hill dalam bukunya Picture Composition Book (1960). Dalam bukunya itu dikatakan bahwa siswa yang baru belajar menulis diperhadapkan pada dua masalah, yaitu apa yang akan ditulis, dan bagaimana mengungkapkannya. Dengan adanya gambar-gambar ini, maka para siswa dituntun untuk menuliskan apa yang tertera dalam gambar dan cara menuliskannya ialah dengan mengikuti urutan gambar yang merupakan urutan peristiwa (narasi), atau menulis apa yanag tertera dalam gambar (deskripsi). Dengan cara ini, para siswa dilatih aspek motorisnya sehingga pada suatu saat siswa dapat menuliskan jenis karangan lain, seperti karangan persuasive (mempengaruhi atau berargumentasi), dan karangan ekspositori atau menjelaskan sesuatu hal.

Melalui media gambar berseri, isi karangan sudah tersedia. Yang masih dibutuhkan ialah menverbalkannya dalam bentuk bahasa yang baik agar bisa komunikatif. Akan tetapi, masih perlu diperiksa apakah para siswa dapat memverbalkannya dengan baik sehingga hasilnya lebih baik dibandingkan dengan 
karangan tanpa media atau dengan cara-cara yang konvensional seperti pemberian informasi, instruksi, dan semacamnya. Hal ini masih perlu diperiksa melalui suatu penelitian.

Berdasarkan latar belakang masalah di atas, masalah penelitian ini dirumuskan dalam bentuk pertanyaan, yaitu: (1) sejauh mana kemampuan siswa-siswa kelas XII pada kelas Bahasa MAN Model Manado mengarang dalam bahasa tulis bahasa Jepang? dan (2) jika kemampuan siswa-siswa kelas XII pada kelas Bahasa MAN Model Manado menulis masih di bawah standar (kurang dari 60), apakah pemberian media melalui gambar berseri dan pemberian kata-kata kunci di bawah pengawasan dan pengamatan langsung oleh guru yang diadakan secara bervariasi, dapat meningkatkan kemampuan mereka menulis dalam bahasa Jepang?

\section{B. Pembahasan}

\section{Acuan Teori Substansi Mata Pelajaran}

\section{a) Menulis Sebagai Aspek Pembelajaran Bahasa Jepang}

Menulis adalah satu dari empat keterampilan yang diajarkan dalam pelajaran bahasa Jepang di sekolah. Menulis adalah suatu pekerjaan yang sukar. Allen dan Valette (dalam Tallei-Pinontoan, 1984:66) mengemukakan bahwa banyak orang yang tidak dapat menulis, bukan hanya dalam bahasa kedua yang sedang dipelajarinya melainkan juga di dalam bahasa ibunya sendiri. Pernyataan ini dibenarkan oleh Tallei-Pinontoan (1984:66) yang menyatakan bahwa pernyataan Allen dan Valette ini ada benarnya karena meskipun seseorang telah mendapat pelajaran dan latihan menulis yang relative memadai, masih belum cukup jaminan bahwa ia akan menjadi penulis yang berhasil.

Pengajaran menulis sebagai suatu kegiatan yang terpusat (integrated) biasanya ditangguhkan sampai murid-murid agak mampu menggunakan bahasa lisan dalam bahasa yang sedang dipelajarinya (Harris, 1969:68). Pengajaran menulis pada tahap awal tidaklah langsung dengan cara melahirkan isi pikiran dan perasaan para murid. Pada tahap ini, murid-murid dilatih untuk dapat meniru bentuk-bentuk huruf (graphics). Tahap yang kedua ialah latihan menggabungkan huruf-huruf (spelling). Tahap yang ketiga ialah latihan untuk melahirkan isi pikiran dan 
perasaan murid-murid (expressing oneself) (Macky, 1969:282). Hal ini sejalan dengan urutan yang diberikan oleh Allen dan Valette (dalam Tallei-Pinontoan, 1984:67), yaitu latihan keterampilan menulis dimulai dengan menyalin dalam bentuk yang paling sederhana sampai kepada latihan menulis bebas.

Salah satu kemampuan yang penting dalam pekerjaan menulis ialah kemampuan mengorganisasi isi pikiran, perasaan, dan pengalaman dalam bentuk paragraf-paragraf. Penulisan paragraf membutuhkan proses yang relatif sama dengan penulisan esai karena ciri-ciri esai mempunyai banyak persamaan dengan ciri-ciri sebuah paragraf. Misalnya, sebuah esai haruslah mempunyai struktur yang jelas dan idenya harus berkembang secara logis. Hal yang serupa harus pula terdapat dalam sebuah paragraf. Maksud (purpose) suatu esai jika dinyatakan disebut tesis. Untuk paragraf, maksud seperti itu dinyatakan dalam bentuk kalimat topik atau kalimat utama (MicCrimmon, 1968:109).

Tahap lebih lanjut dalam pengajaran menulis ialah menulis bebas dan inilah tujuan pengajaran menulis yang sebenarnya. Menulis bebas ini pula yang tersukar di antara tahap menulis yang telah disebutkan di atas. Menurut Adelstein dan Prival (dalam Tallei-Pinontoan, 1984:69), anggapan guru yang mengatakan bahwa murid pada dasarnya gemar belajar menulis adalah keliru. Lanjut dikatakan oleh kedua penulis itu, menulis adalah salah satu kegiatan manusia yang membingungkan, menimbulkan frustasi, dan menjengkelkan.

Menulis bebas dilakukan bila pelajar telah terlatih dalam cara-cara menulis seperti yang telah disebutkan di muka. Untuk tulisan bebas, Machmoed (1979:933) mengemukakan beberapa contoh, yaitu eksposisi sederhana, cerita (narasi), argumentasi dan opini, dan kritik serta analisis. Dalam tulisan Machmoed tersebut tidak disebutkan pada tingkat mana jenis-jenis karangan itu diberikan. Berdasarkan Kurikulum Sekolah Menengah Atas (SMA) 2003, semua jenis karangan yang disebutkan oleh Machmoed tercakup dalam kurikulum tersebut dan lebih dipertajam dengan penulisan paragraf, pemakaian kalimat yang efektif, dan perluasan penggunaan kosa kata.

Di sekolah dasar, menulis bebas juga sudah dilatihkan. Hal itu tampak pada beberapa subpokok bahasan yang menentukan topik-topik tulisan apa yang 
dilatihkan di samping latihan menulis surat. Untuk sekolah lanjutan tingkat pertama, materi pengajaran menulis tampaknya hanya merupakan perluasan dan pengalaman dari materi pengajaran menulis sekolah dasar ditambah dengan beberapa variasi seperti penggunaan beberapa gaya bahasa dalam surat, bahasa iklan, membuat laporan, notulen rapat, dan lain-lain.

Diasumsikan, pengajaran menulis yang konvensional, yang hanya memberikan topic dan judul tulisan tertentu, bahkan kadang-kadang tulisan bebas diduga menjadi salah satu faktor pemicu rendahnya tingkat keterampilan siswa dalam menghasilkan tulisan yang baik. Karena itu, pemberian media berupa gambar berseri dan kata-kata kunci dapat menjadi alternatif latihan menulis yang efektif. Dan, dengan begitu keterampilan menulis siswa dapat ditingkatkan secara maksimal.

\section{b) Menulis dengan Teknik Gambar Berseri}

Alat bantu pembelajaran, termasuk alat bantu pembelajaran bahasa Jepang yang dapat digunakan ialah gambar-gambar berseri. Gambar-gambar seperti itu bermacam-macam. Ada berupa hasil pemotretan, ada hasil lukisan, dan ada yang berupa sketsa. Gambar-gambar seperti itu sangat membantu efektivitas hasil pengajaran di samping karena dapat membantu pemahaman para siswa, juga sangat membantu menjelaskan benda-benda yang jarang atau tidak pernah dilihat oleh siswa. Karena itu, terdapat banyak penelitian untuk mengetahui sejauh mana efektivitas gambar sebagai media pengajaran. Hal itu dikemukakan oleh Herbert dan Scuozo (1967:178). Dikatakan oleh kedua penulis itu bahwa hasil penelitian mengenai gambar diam (still pictures) menghasilkan beberapa temuan, antara lain:

a. Gambar merangsang minat para siswa.

b. Gambar-gambar membantu siswa untuk memahami dan mengingat-ingat isi dari materi verbal yang menyertai gambar tersebut.

c. Gambar-gambar dengan garis sederhana sering lebih efektif sebagai pemindah informasi dibandingkan dengan gambar yang banyak hiasannya, atau dibandingkan dengan gambar hasil fotografi dari kehidupan nyata yang terlalu banyak kandungan informasi visualnya. Gambar-gambar 
dengan banyak hiasannya atau hasil fotografi mengandung terlalu banyak informasi dan kurang baik digunakan sebagai media pendidikan, terutama pada anak-anak yang masih muda. Gambar-gambar dengan coretan sederhana lebih efektif sebagai pemindah informasi.

d. Penggunaan warna sering memiliki masalah. Meskipun warna dapat menimbulkan minat para siswa melebihi gambar hitam-putih, tetapi tidak selalu harus menjadi pilihan untuk dipakai sebagai media pengajaran. Sebuah hasil penelitian menyarankan bahwa jika warna digunakan, haruslah realistic, bukan hanya sekedar untuk keperluannya. Jika kita mengajarkan yang berhubungan dengan konsep warna, maka harus digunakan warna sesuai aslinya.

Menurut Herbert dan Scuorzo (1967:167), gambar-gambar yang dipakai sebagai media pengajaran, dapat memperkuat kesan atau impresi, memberikan fakta baru, atau membentuk landasan pada pengembangan pemilahan makna. Para siswa dan guru memperoleh keuntungan dari latihan-latihan yang ditujukan kepada pemorolehan makna dari gambar-gambar. Selanjutnya dikatakan oleh kedua penulis itu (hal. 173), latihan-latihan belajar membaca gambar-gambar dalam beberapa hal menyerupai belajar belajar membaca teks. Karena itu, praktek dalam mambaca gambar memberi pengalaman yang berharga bagi setiap siswa. Kesadaran tentang pentingnya teks visual memberikan daya dorong terhadap aktivitas pelibatan gambar.

Apa yang dikatakan oleh kedua penulis di atas memberi bukti tentang pentingnya gambar-gambar dalam pengajaran, termasuk pengajaran bahasa. Tanpa gambar, semua menjadi abstrak. Penggunaan gambar juga memberi motivasi dan pada gilirannya para siswa menjadi tertarik terhadap materi pengajaran yang diberikan. Tanpa gambar, semuanya menjadi abstrak dan dengan demikian, para siswa kurang tertarik mengikuti pelajaran. Simbol kata dengan teknik penyajian melalui simbol-simbol tertulis dapat membosankan terutama jika guru itu sendiri tidak terampil menyajikannya. Dengan gambar-gambar, para siswa dapat mengolah sendiri pesan yang terdapat di dalamnya sehingga para siswa menjadi aktif dan motivasi belajarnya meningkat. 
Hasil peneitian eksperimental Canning-Wilson (2001) menunjukkan bahwa pemakaian stimuli (rangsangan) visual (penglihatan) memungkinkan para pembelajar bahasa dapat lebih akurat dalam mendeskripsikan cara kerja suatu alat pencampur (pengadon). Kelompok yang dilengkapi dengan gambar, 92\% berhasil menyelesaikan tugasnya dengan baik, sedangkan kelompok yang tidak diberi stimuli visual hanya 52\% yang berhasil dengan baik. Gambar-gambar memungkinkan para siswa menginterprestasi secara rinci dibandingkan dengan siswa yang hanya diberi penjelasan secara verbal (ceramah) (Dikutip bebas melalui internet http://www.eltnewsletter.com/back/feb2001/art482001.htm).

Dalam sumber yang sama, Canning-Wilson mengatakan bahwa pemakaian stimuli visual berupa gambar dalam konteks pengajaran bahasa mempertinggi sensitivitas siswa terhadap bahasa dan kemampuan mereka menciptakan hubungan-hubungan kata. Imaji grafik menjadikan para siswa lebih berpikir secara lebih rinci dan lebih responsif. Lagi pula, pemberian gambar-gambar memungkinkan para siswa mengembangkan imajinasinya sehingga mampu berpikir secara abstark dan sistematis.

Gambar berseri seperti ini telah pula dicobakan oleh Hill seperti yang disebutkan dalam disebutkan dalam bukunya (1960) dan dikatakannya gambargambar merupakan alat test yang baik, bukan hanya untuk karangan tertulis, tetapi juga untuk alat test yang baik, bukan hanya untuk karangan tertulis, tetapi juga untuk alat tes pada berbagai jenis test lainnya, seperti pemahaman oral, test kosakata, dan test struktur kalimat. Dapat juga ditambahkan bahwa kemampuan ejaan juga dapat ditest melalui sistem bergambar ini.

Penelitian dan kajian tersebut diadakan dinegara lain yang berbahasa Inggris. Di Indonesia sendiri, setahu penulis, belum pernah dilaksanakan melalui penelitian yang sistematis. Karena itu, penelitian tindakan kelas ini sangat relevan untuk dilaksanakan.

\section{Acuan Teoritik Konseptual Tindakan yang Dipilih}

Gambar-gambar merupakan alat pengalaman di samping alat-alat pengalaman lainnya seperti benda tiruan, pengalaman langsung, dan sebagainya. Dalam hal ini perlu disimak apa yang disebutkan oleh Edgar Dale (dalam Solchan, Rofi'uddin, 
dan Budiasih, 1998:2.4) sebagai "cone of experience" atau kerucut pengalaman yang membagi pengalaman secara hierarkhis (sebelah susun), mulai dari yang paling kongkret yaitu pengalaman langsung sebagai dasar kerucut sampai kepada pengalaman yang paling abstrak dalam bentuk lambing-lambang yang merupakan puncak kerucutnya. Gambar-gambar merupakan tingkatan yang kesepuluh.

Secara rinci, hirarki Dale dalam kerucut pengalamannya dilukiskan sebagai berikut:

1. Pengalaman langsung berupa pengalaman secara alamiah sehari-hari.

2. Pengalaman tiruan berupa simulasi seperti dipraktekkannya rapat-rapat di kelas.

3. Pengalaman dramatisasi. Nomor 2 dan 3 ini dimaksudkan untuk meningkatkan kemampuan berbicara.

4. Pengalaman percontohan berupa contoh gerakan-gerakan dan tiruan benda-benda sebagai alat peraga.

5. Pengalaman dramatisasi yang dibuat secara khusus, kemudian para siswa membuat laporan tentang hasil kunjungannya ke objek tertentu.

6. Pengalaman pameran dan museum.

7. Pengalaman televisi.

8. Pengalaman gambar hidup, baik gambar-gambar bisu maupun dengan suara atau bunyi. Pengalaman no.7 hampir sama dengan no.8

9. Pengalaman audio seperti radio, dan kaset rekaman suara. Nomor 9 ini lebih abstrak dibandingkan dengan pengalaman-pengalaman seperti yang disebutkan di atas karena pengalaman ini hanya melibatkan rangsangan yang terbatas (hanya suara).

10. Pengalaman lambing visual berupa gambar. Gambar, terutama gambar berseri dapat dimanfaatkan untuk meningkatkan kemampuan berbicara dan menulis.

11. Yang terakhir, dan yang paling abstrak ialah pemakaian lambing-lambang bahasa berupa kata. Hal ini merupakan lambing verbal (Dale, dalam Solchan, Rofi’uddin, dan Budiasih, 1998:206) 
Cerita dapat divisualkan dalam bentuk gambar berseri. Hal ini telah dikerjakan oleh Tallei (1972) dalam bentuk cerita bergambar yang terdiri atas 13 cerita. Setiap cerita terdiri atas 8 seri dengan pemberian kata-kata kunci pada setiap cerita gambar.

Menurut Sapani, Mulyati, dan Idris (1998), untuk menumbuhkan keterampilan menulis/mengarang, teknik yang dapat digunakan antara lain ialah (1) teknik mengarang gambar, (2) teknik meringkas, (3) teknik menyadur, (4) teknik melanjutkan karangan, dan (5) teknik mendeskripsikan objek. Dalam kelima teknik tersebut, teknik dengan menggunakan gambar diyakini paling efektif. Teknik mendeskripsikan objek umpamanya, dapat dibantu dengan gambargambar agar hasil karangan lebih baik. Oleh karena itu, dalam penelitian ini, tindakan yang dipilih adalah pembelajaran menulis dengan teknik gambar berseri yang dilengkapi dengan kata-kata kunci. Gambar-gambar berseri yang digunakan diambil dari buku Latihan Mengarang (Jilid I) yang disusun oleh Tallei (1972). Buku yang disusun oleh Tallei ini dicetak ulang pada tahun 2004 dalam dua versi, yaitu bahasa Indonesia dan bahasa Inggris. Untuk kepentingan penggunaannya dalam penelitian ini, beberapa bagian dari buku itu yang digunakan sebagai media pembelajaran, kata-kata kuncinya diterjemahkan sesuai dengan kata-kata dalam bahasa Jepang.

\section{Hipotesis Tindakan}

Menulis adalah merupakan keterampilan berbahasa aktif produktif. Sebagai suatu keterampilan aktif produktif, maka pemerolehannya perlu dengan latihan yang intensif. Latihan yang intensif tersebut perlu dipolakan agar memperoleh hasil yang maksimal. Salah satu pola yang perlu dilatihkan secara intensif adalah pemberian gambar-gambar berseri yang disertai dengan kata-kata kunci kepada siswa sebelum mereka mulai menulis. Jadi, diasumsikan bahwa siswa akan jauh lebih efektif dalam menulis dengan menggunakan panduan gambar-gambar berseri serta kata-kata kunci. Berdasarkan pada asumsi ini, maka hipotesis penelitian tindakan kelas ini dirumuskan sebagai berikut: 
"Hasil tulisan siswa dalam bahasa Jepang dapat ditingkatkan dengan menggunakan media gambar berseri dengan disertai kata-kata kunci, dibandingkan dengan tidak menggunakan media gambar berseri, tetapi hanya dalam bentuk ceramah dan diberi kata-kata kunci yang sama"

\section{METODOLOGI PENELITIAN}

\section{A. Metode Penelitian}

Penelitian ini menggunakan metode penelitian tindakan kelas (PTK). Dalam PTK, alur tindakan berlangsung dalam beberapa siklus karena setiap siklus dievaluasi tingkat keberhasilan tindakan yang diberikan untuk ditindaklanjuti. Dalam setiap tindak lanjut, dipecahkan masalah yang timbul pada siklus yang mendahuluinya. Banyaknya siklus tergantung kepada tingkat keberhasilan yang dicapai.

\section{B. Lokasi dan Subjek Penelitian}

Penelitian tindakan kelas ini dilaksanakan pada Madrasah Aliyah Negeri (MAN) Model Manado. Dalam penelitian tindakan kelas, tidak diperlukan populasi dan sampel. Yang diperlukan ialah sumber data, yang selanjutnya disebut subjek penelitian. Sumber data atau subjek PTK ini ialah siswa kelas XII MAN Model Manado yang berjumlah 20 siswa.

\section{Rencana Tindakan}

Masalah yang diteliti hanyalah masalah yang dihadapi di kelas tempat peneliti mengajar. Rencana tindakan yang ditempuh mengikuti langkah-langkah baku dalam PTK seperti yang disarankan oleh Tallei-Pinontoan (1999) sebagai berikut:

(1) Perencanaan, yaitu tes awal, pembuatan scenario pembelajaran, dan evaluasi.

(2) Implementasi Tindakan, yaitu pelaksanaan tindakan yang digelar.

(3) Observasi, yaitu uraian tentang prosedur pencatatan hasil pengamatan dan penafsiran data mengenai proses dan produk dari implementasi tindakan. 
(4) Analisis Hasil Evaluasi dan Refleksi, yaitu uraian tentang prosedur analisis terhadap hasil pemantauan dan refleksi berkenaan dengan proses dan dampak tindakan perbaikan yang digelar.

\section{Data dan Cara Pengumpulannya}

Jenis data yang dikumpulkan ialah skor tingkat kemampuan menulis siswa dalam bahasa Jepang. Dalam menilai tulisan siswa digunakan 6 indikator penilaian. Setiap indicator diberikan bobot yang berbeda sesuai dengan tingkat kesulitannya. Untuk jelasnya indicator penilaian dan pembobotannya disajikan dalam Tabel 1 berikut.

Tabel 1. Indikator Penilaian Karangan dan Pembobotannya

\begin{tabular}{|c|l|c|}
\hline No. & \multicolumn{1}{|c|}{ Indikator Karangan } & Bobot Skor \\
\hline 1. & Isi & 24 \\
\hline 2. & Organisasi Karangan & 22 \\
\hline 3. & Wacana & 20 \\
\hline 4. & Tata Kalimat & 12 \\
\hline 5. & Kosakata & 12 \\
\hline 6. & Ejaan Jumlah Skor & 10 \\
\hline & & $\mathbf{1 0 0}$ \\
\hline
\end{tabular}

\section{E. Teknik Analisis Data}

Data analisis data penilaian ini, ditempuh prosedur analisis baku dalam PTK seperti yang disarankan oleh Tallei-Pinontoan (1999) sebagai berikut:

a. Setting. Settingnya ialah kelas tempat peneliti mengajar sehari-hari.

b. Variabel yang diteliti. Variabel yang diteliti ialah variabel input berupa bahan ajar yang dalam hal ini ialah kemampuan siswa kelas XII pada Kelas Bahasa MAN Model Manado menulis dalam bahasa Jepang dengan menggunakan alat bantu berupa gambar berseri dan kata-kata kunci.

c. Rencana Tindakan. (Lihat bagian B di atas)

d. Data dan cara pengumpulannya. Jenis data yang dikumpulkan ialah skor tingkat kemampuan siswa menulis dalam bahasa Jepang. 
e. Indikator Kinerja. Tolok ukur keberhasilan ialah membandingkan hasil pengukuran pada tes awal dengan pengukuran tes akhir pada setiap siklus atau putaran tindakan. Skor yang dibandingkan adalah skor rata-rata. Rumus untuk menghitung rata-rata ialah:

$$
\mathrm{R}=\frac{\sum X i}{\mathrm{~S}} \quad \text { (Sudjana, 1989) }
$$

Catatan: $\sum=$ sigma atau jumlah semua

$$
\begin{aligned}
& X i=\text { skor setiap siswa } \\
& \mathrm{S}=\text { jumlah siswa } \\
& \mathrm{R}=\text { rata-rata }
\end{aligned}
$$

\section{HASIL PENELITIAN}

\section{A. Deskripsi Hasil Penelitian}

\section{Pelaksanaan Tindakan Putaran Pertama}

Pada pelaksanaan putaran pertama dilakukan tes awal untuk mengetahui kemampuan awal para siswa dalam menulis untuk dibandingkan dengan hasil peningkan sesudah pemberian tindakan. Informasi ini penting agar perlakuan yang diberikan dapat diketahui berhasil atau tidak. Hasil tes awal menunjukkan bahwa skor rata-rata yang diperoleh 53,4 di bawah nilai standar yang ditetapkan yaitu 60 . Berdasarkan pada hasil tes awal yang dilakukan tampak bahwa kemampuan ratarata siswa masih cukup rendah yaitu 53,4. Ini berarti bahwa kemampuan siswa perlu ditingkatkan.

Pelaksanaan pemberian tindakan dalam putaran pertama dimulai dengan persiapan dan perumusan masalah yang akan dipecahkan. Perumusan masalah ini mengacu kepada rumusan masalah penelitian yang telah dikemukakan dalam Bab I. masalah dalam butir pertama dijawab melalui tes awal, sedangkan jawaban atas pertanyaan kedua dijawab melalui metode tindakan dengan pemberian media melalui gambar berseri dan pemberian kata-kata kunci dalam bahasa Jepang di 
bawah pengawasan dan pengamatan langsung oleh guru (peneliti) yang diadakan secara bervariasi.

Masalah yang perlu dipecahkan dalam putaran ini sesuai dengan rumusan masalah yang tertera dalam Bab I khususnya pada bagian 2. Sesuai dengan teori yang dibahas, maka untuk meningkatkan kemampuan menulis siswa, maka perlu dijelaskan lebih dahulu teori-teori tentang keterampilan menulis bahasa Jepang khususnya berkaitan dengan tulisan kanji, hiragana, katakana, penjelasan tentang unsur-unsur tulisan/karangan terutama mengenai paragraf yang meliputi unsur topik, kalimat utama, kalimat penjelas, konjungsi antarkalimat dan antarparagraf, penulisan ejaan, dan tanda-tanda baca dalam bahasa Jepang.

Selanjutnya, guru/peneliti memberi banyak tugas menulis dan mengawasinya. Ini semua didiskusikan dan peneliti mengadakan pengawasan dan menyediakan alat bantu berupa media pengajaran, yaitu gambar-gambar berseri yang dilengkapi dengan kata-kata kunci. Hal ini berlangsung selama dua minggu dan diakhiri dengan kegiatan evaluasi.

Setelah pemberian tindakan seperti dikemukakan di atas, maka diadakan evaluasi untuk melihat keberhasilan tindakan yang diberikan pada putaran pertama. Hasil evaluasi menunjukkan adanya peningkatan dari skor rata-rata 53,4 pada tes awal menjadi 64,6 pada akhir putaran pertama. Hasil ini dianggap belum memadai karena targetnya, yaitu minimal 85 belum tercapai. Untuk jelasnya rerata skor setiap indicator penilaian karangan dapat dilihat dalam Tabel 2.

Telah dikemukakan bahwa hasil yang dicapai pada siklus pertama belum memadai. Hal yang mengganjal para siswa ialah masih relatif rendahnya skor rata-rata siswa pada hampir semua aspek penilaian. Untuk ejaan (rerata skor 7,5), kosakata (rerata skor 6,3), tata kalimat (rerata skor 5,9), wacana (rerata skor 13,1), organisasi karangan (rerata skor 12,1), da nisi karangan (rerata skor 13,7). Karena itu, tindakan perlu diteruskan pada siklus putaran kedua. 
Tabel 2. Rata-rata Skor Indikator Penilaian Karangan pada Siklus I

\begin{tabular}{|c|l|c|}
\hline No. & \multicolumn{1}{|c|}{ Indikator Karangan } & Rata-rata Skor \\
\hline 1. & Isi & 15,0 \\
\hline 2. & Organisasi Karangan & 13,9 \\
\hline 3. & Wacana & 14,4 \\
\hline 4. & Tata Kalimat & 6,0 \\
\hline 5. & Kosakata & 6,5 \\
\hline 6. & Ejaan & 8,8 \\
\hline
\end{tabular}

\section{Pelaksanaan Tindakan Putaran Kedua}

Dalam siklus kedua ini penekanannya diberikan kepada masalah aspek-aspek yang masih lemah pada hasil evaluasi putaran pertama. Hal ini dilaksanakan melalui pemberian tugas mengarang dengan dibantu oleh alat bantu atau media pengajaran berupa gambar berseri yang disertai dengan kata kuncinya. Setelah tindakan berjalan selama dua minggu, maka diadakan evaluasi untuk melihat keberhasilan pemberian tindakan pada putaran kedua. Hasil evaluasi menunjukkan adanya peningkatan dari skor rata-rata 64,6 pada putaran pertama menjadi 77,4 pada putaran kedua. Skor rata-rata ini belum mencapai target sehingga penelitian perlu dilanjutkan ke putaran ketiga. Skor setiap indicator karangan pada siklus atau putaran kedua tampak dalam Tabel 3 berikut.

Tabel 3. Rata-rata Skor Indikator Penilaian Karangan pada Siklus II

\begin{tabular}{|c|l|c|}
\hline No. & \multicolumn{1}{|c|}{ Indikator Karangan } & Rata-rata Skor \\
\hline 1. & Isi & 17,1 \\
\hline 2. & Organisasi Karangan & 16,5 \\
\hline 3. & Wacana & 15,2 \\
\hline 4. & Tata Kalimat & 9,3 \\
\hline 5. & Kosakata & 10,1 \\
\hline 6. & Ejaan & 9,2 \\
\hline
\end{tabular}

Dalam evaluasi yang diadakan pada akhir putaran kedua, tampak adanya peningkatan yang berarti, dari 64,6 pada putaran pertama menjadi 77,4 pada putaran kedua. Namun, karena belum mencapai target, maka penelitian perlu 
dilanjutkan ke putaran ketiga. Artinya, bahwa hal-hal yang belum tuntas pada putaran kedua, perlu ditindaklanjuti pada putaran ketiga. Hal-hal yang perlu ditindaklanjuti ialah masalah tata kalimat, keutuhan wacana, organisasi karangan, dan isi karangan yang tampak masih rendah rerata skornya pada hampir sebagian siswa.

\section{Pelaksanaan Tindakan Putaran Ketiga}

Masalah yang akan dipecahkan pada putaran ketiga ialah upaya apa yang dijalankan oleh peneliti agar para siswa kelas XII MAN Model Manado dapat mengembangkan tulisan yang memiliki unsur tata kalimat yang tersusun dengan baik, menyusun karangan dengan wacana yang utuh, menata atau mengorganisasi karangan secara apik, da nisi karangan yang baik? Untuk menjawab permasalahan ini diperlukan tindakan dalam bentuk praktek pembelajaran mengarang dengan gambar berseri disertai dengan kata-kata kuncinya.

Pemecahan masalah ini ialah dengan memperbanyak penugasan dan latihan mengurang. Bahasa sebagai aspek keterampilan, membutuhkan latihan yang intensif agar dapat dikuasai secara otomatis. Untuk itu, dalam putaran ketiga ini penekanan kepada aspek tata kalimat, wacana, organisasi karangan, dan isi. Hal ini berlangsung selama dua minggu. Peneliti menugaskan siswa untuk menyusun karangan dengan pemberian alat bantu berupa gambar berseri dan kata-kata kunci. Pekerjaan mereka didiskusikan dalam kelas di bawah pengawasan guru/peneliti. Sambil berdiskusi, guru/peneliti mengadakan pengamatan atau observasi untuk memantau kegiatan siswa. Mereka yang tidak aktif, dibimbing agar turut berpartisipasi dalam diskusi. Setelah kegiatan berlangsung selama dua minggu, diadakan evaluasi untuk melihat tingkat keberhasilan tindakan yang diberikan.

Seperti disebutkan di atas, hasil evaluasi menunjukkan adanya peningkatan yang berarti dari skor rata-rata 77,4 pada putaran kedua, meningkat menjadi 83,7. Rata-rata yang diperoleh siswa ini sudah menunjukkan nilai yang signifikan, namun belum mencapai target yang diharapkan yaitu 85. Karena itu, perlu pelaksanaan tindakan berikutnya. Untuk jelasnya, hasil evaluasi karangan siswa pada siklus III ini disajikan dalam Table 4 berikut.

Tabel 4. Rata-rata Skor Indikator Penilaian Karangan pada Siklus III 


\begin{tabular}{|c|l|c|}
\hline No. & \multicolumn{1}{|c|}{ Indikator Karangan } & Rata-rata Skor \\
\hline 1. & Isi & 17,7 \\
\hline 2. & Organisasi Karangan & 18,2 \\
\hline 3. & Wacana & 18,0 \\
\hline 4. & Tata Kalimat & 9,9 \\
\hline 5. & Kosakata & 10,5 \\
\hline 6. & Ejaan & 9,5 \\
\hline
\end{tabular}

Sudah disebutkan bahwa apa yang dicapai dalam pelaksanaan tindakan putaran ketiga ini sudah signifikan, namun belum mencapai target yang diharapkan. Nilai rata-rata karangan yang diperoleh adalah 83,7. Dalam beberapa aspek penilaian masih terdapat nilai rata-rata yang rendah, yaitu antara lain pada aspek wacana, organisasi karangan, dan isi. Karena itu, ketiga aspek ini perlu dicari pemecahannya melalui pemberian tindakan pada siklus selanjutnya.

\section{Pelaksanaan Tindakan Putaran Keempat}

Masalah yang akan dipecahkan pada putaran keempat ini ialah upaya apa yang dijalankan oleh peneliti agar para siswa kelas XII (kelas Bahasa) MAN Model Manado dapat menyusun karangan yang memiliki keutuhan wacana, organisasi karangan yang baik, da nisi karangan yang baik. Untuk memecahkan masalah ini diperbanyak penugasan dan latihan mengarang. Latihan adalah cara yang paling efektif untuk meningkatkan keterampilan menulis. Dalam latihan ini, peneliti memberikan penjelasan-penjelasan tentang aspek keutuhan wacana, organisasi karangan dan aspek isi karangan kepada setiap siswa yang telah dibagi dalam beberapa kelompok kerja. Hal ini berlangsung selama dua minggu. Peneliti menugaskan siswa untuk menyusun karangan dengan pemberian alat bantu berupa gambar berseri dan kata-kata kunci. Hasil pekerjaan mereka didiskusikan dalam kelas di bawah pengawasan peneliti. Sambil berdiskusi, peneliti mengadakan pengamatan atau observasi untuk memantau kegiatan siswa. Mereka yang tidak aktif, dibimbing agar turut berpartisipasi dalam diskusi. Setelah kegiatan berlangsung selama dua minggu, diadakan evaluasi untuk melihat tingkat keberhasilan tindakan yang diberikan. 
Setelah kegiatan pemberian tindakan sudah berlangsung dua minggu, diadakan evaluasi untuk melihat tingkat keberhasilan pemberian tindakan. Hasil evaluasi menunjukkan adanya peningkatan yang signifikan dari skor rata-rata 83,7, pada putaran ketiga, meningkat menjadi 87,6. Rata-rata yang diperoleh siswa ini sudah menunjukkan nilai yang sangat signifikan dan sudah mencapai target yang diharapkan.

\section{Tabel 5. Rata-rata Skor Indikator Penilaian Karangan pada Siklus IV}

\begin{tabular}{|c|l|c|}
\hline No. & \multicolumn{1}{|c|}{ Indikator Karangan } & Rata-rata Skor \\
\hline 1. & Isi & 17,8 \\
\hline 2. & Organisasi Karangan & 19,2 \\
\hline 3. & Wacana & 18,9 \\
\hline 4. & Tata Kalimat & 11,1 \\
\hline 5. & Kosakata & 10,8 \\
\hline 6. & Ejaan & 9,9 \\
\hline
\end{tabular}

Sudah disebutkan bahwa apa yang dicapai dalam pelaksanaan tindakan putaran keempat ini sudah signifikan yaitu rata-rata 87,6. Nilai rata-rata karangan yang diperoleh ini dianggap cukup meyakinkan sehingga pemberian tindakan tidak perlu dilanjutkan. Dengan kata lain, target yang diharapkan sudah tercapai di mana standar minimal rata-rata karangan yang diharapkan yaitu 85. Data dalam Tabel 6 berikut secara jelas memperlihatkan perkembangan kemampuan siswa dalam menyusun karangan. 
Tabel 6. Skor Perolehan Siswa pada Siklus Putaran

\begin{tabular}{|l|l|c|c|c|c|}
\hline \multirow{2}{*}{ No } & \multirow{2}{*}{ NAMA SISWA } & \multicolumn{4}{|c|}{ Skor Setiap Siklus } \\
\cline { 3 - 6 } & & Siklus I & Siklus II & Siklus III & Siklus IV \\
\hline 1 & Abdul Bachdin & 64 & 74 & 80 & 88 \\
\hline 2 & Ahmad Safik Mufti & 65 & 80 & 83 & 86 \\
\hline 3 & Amanda R. Usulu & 65 & 76 & 82 & 86 \\
\hline 4 & Balgis Palar & 71 & 81 & 91 & 92 \\
\hline 5 & Delia Mustaring & 58 & 71 & 83 & 87 \\
\hline 6 & Deny Ismail & 66 & 77 & 82 & 86 \\
\hline 7 & Fahlun Lahaji & 64 & 84 & 89 & 92 \\
\hline 8 & Julaiha Sune & 67 & 76 & 83 & 89 \\
\hline 9 & Kartini Muarif & 71 & 81 & 87 & 91 \\
\hline 10 & Koryati Djado & 65 & 81 & 88 & 89 \\
\hline 11 & Lita C. Norang & 62 & 76 & 82 & 85 \\
\hline 12 & Noval S. Bayahi & 61 & 72 & 80 & 85 \\
\hline 13 & Nurhayati Hasan & 63 & 73 & 80 & 84 \\
\hline 14 & Ririn Yanis & 74 & 84 & 88 & 88 \\
\hline 15 & Rizky R. Gobel & 59 & 74 & 84 & 87 \\
\hline 16 & Rostiana Dama & 59 & 74 & 80 & 86 \\
\hline 17 & Safran Due & 72 & 85 & 90 & 90 \\
\hline 18 & Syarif Hidayatullah & 60 & 73 & 78 & 84 \\
\hline 19 & Taufik Muzakar & 62 & 76 & 78 & 86 \\
\hline 20 & Ulfa & 63 & 79 & 86 & 90 \\
\hline & Rata-rata & $\mathbf{6 4 , 6}$ & $\mathbf{7 7 , 4}$ & $\mathbf{8 3 , 7}$ & $\mathbf{8 7 , 6}$ \\
\hline & & & & & \\
\hline & & 63 & 79 & 82 \\
\hline
\end{tabular}

\section{B. Deskripsi Model Tindakan}

Penelitian ini adalah penelitian tindakan kelas. Disebut demikian karena setting atau latarnya adalah kelas. Model tindakan yang dilakukan khususnya dalam pembelajaran keterampilan mengarang ialah dengan pemberian alat bantu 
berupa gambar berseri yang dilengkapi dengan kata-kata kunci. Pemberian tindakan itu dilakukan dengan tahapan.

1. Pertama-tama siswa dikelompokkan dalam beberapa kelompok. Banyaknya siswa dalam kelompok tidak lebih dari 3 orang. Hal ini bertujuan agar keterlibatan siswa dalam kelompok berlangsung maksimal.

2. Setelah kelompok siswa terbentuk, guru memberikan tugas mengarang yang dikerjakan secara berkelompok. Jadi, setiap kelompok diberikan gambar berseri yang dilengkapi dengan kata-kata kunci. Gambar-gambar yang diberikan pada setiap kelompok diupayakan tidak sama untuk masing-masing kelompok. Hal ini bertujuan untuk memperkaya masalah atau tema karangan. Dengan gambar-gambar yang bervariasi, juga diharapkan perbendaharaan kosakata siswa meningkat.

3. Setelah karangan setiap kelompok siswa selesai, dikumpulkan pada guru untuk kemudian didiskusikan kembali dalam kelas, sehingga setiap siswa dapat mengetahui kekurangan atau kesalahan mereka. Setiap kesalahan siswa dalam karangan harus dikoreksi dan dijelaskan oleh guru.

4. Setelah metode diskusi kelompok sudah dianggap tuntas, maka tugas mengarang secara individual perlu dilaksanakan. Hal ini untuk mengetahui perkembangan keterampilan mengarang setiap siswa. Hasil karangan setiap siswa dikumpul pada guru dan didiskusikan. Setiap kekurangan dan kesalahan dikoreksi dan dijalaskan oleh guru.

\section{Pembahasan Hasil}

Berdasarkan temuan-temuan penelitian dalam setiap tindakan pembelajaran yang dilakukan pada setiap siklus, maka dapat dikemukakan bahwa pembelajaran bahasa Jepang khususnya pada aspek keterampilan menulis haruslah diperkaya dengan latihan. Dalam praktek-praktek latihan, para siswa tidak cukup hanya dengan memberikan topik atau tema tulisan/karangan saja, tetapi harus dilakukan dengan pemberian alat bantu atau media pembelajaran. Media atau alat bantu pembelajaran yang efektif berdasarkan hasil penelitian tindakan kelas ini ialah gambar berseri yang disertai dengan kata-kata kunci pada setiap seri. 
Hasil penelitian juga menunjukkan bahwa apa yang telah dikerjakan oleh Hill (1960) dalam upayanya untuk memperkenalkan media mengarang dalam bentuk Picture Composition Book (1960), (Buku Karangan Bergambar) relevan dengan hasil temuan penelitian ini. Dengan adanya media pembelajaran berupa gambargambar ini, para siswa dituntun untuk menuliskan apa yang tertera dalam gambar dan cara menuliskannya ialah dengan mengikuti urutan gambar yang merupakan urutan peristiwa (narasi), atau menulis apa yang tertera dalam gambar (deskripsi). Dengan cara ini, para siswa dilatih aspek motorisnya sehingga pada suatu saat siswa dapat menuliskan jenis karangan lain, seperti karangan persuasive (mempengaruhi atau berargumentasi), dan karangan ekspositori atau menjelaskan sesuatu hal.

Ternyata siswa-siswa dapat secara aktif dan kreatif dalam menyusun karangan melalui media gambar berseri yang disajikan. Kendala umum seperti siswa tidak memiliki ide ternyata dapat dipecahkan melalui pemberian gambar berseri. Selain itu, motivasi siswa pun meningkat. Motivasi ini menjadi bagian penting dalam proses pembelajaran. Tanpa motivasi yang kuat, apapun yang direncanakan oleh guru tidak akan tercapai secara maksimal.

Jadi, berpedoman pada hasil penelitian tindakan kelas yang dilakukan ini dapatlah dikemukakan bahwa pemberian alat bantu berupa gambar berseri yang disertai dengan kata-kata kuncinya menunjukkan hasil yang lebih efektif dibandingkan dengan pemberian tugas menulis tanpa media atau dengan cara-cara yang konvensional seperti pemberian informasi, instruksi, dan semacamnya. Hal ini sudah dibuktikan melalui penelitian tindakan kelas ini.

\section{Kesimpulan dan Saran}

Hasil-hasil pemberian tindakan setiap siklus menunjukkan adanya peningkatan secara signifikan atau berarti, bukannya kebetulan. Hal itu tampak pada peningkatan kemampuan siswa kelas XII (kelas Bahasa) MAN Model Manado dari siklus ke siklus. Siklus pertama menunjukkan skor rata-rata 64,6 dari hasil tes awal 53,4. Pada siklus berikutnya, yaitu siklus kedua terjadi lagi peningkatan 
menjadi 77,4. Siklus ketiga 83,7 dan pada siklus yang keempat atau yang terakhir, skor rata-rata siswa meningkat menjadi 87,6.

Temuan di atas menunjukkan bahwa pemberian tindakan dengan teknik pemberian alat bantu berupa media gambar berseri disertai dengan kata-kata kunci, ternyata efektif digunakan untuk meningkatkan kemampuan siswa menulis dalaam bahasa Jepang.

Berdasarkan kenyataan bahwa pemberian tugas menulis dengan menggunakan alat bantu atau media berupa gambar berseri yang disertai dengan kata-kata kunci efektif untuk meningkatkan kemampuan siswa menulis dalam bahasa tulis bahasa Jepang, maka disarankan pada para guru agar dalam latihan-latihan atau tugastugas menulis dalam pembelajaran bahasa yang diberikan kepada para siswa mestilah menggunakan lebih banyak alat bantu atau media pembelajaran berupa gambar-gambar berseri yang disertai dengan kata-kata kunci. Hal ini penting dikemukakan untuk menghentikan keluhan tentang rendahnya kemampuan para siswa dalam keterampilan menulis khususnya keterampilan menulis dalam bahasa Jepang. 


\section{Daftar Pustaka}

Brown, Douglas. 1980. Principles of Language Learning and Teaching. New York: Prentice Hall Regents

Canning-Wilson, Christine. 2001. Visual and Language Learning, Is there a Connection? Dikutip melalui fasilitas Internet

Finocchiaro, Marry \& Michael Bonomo. 1973. The Foreign Language Learner. New York: Regents Publishing Company

Harris, David P. 1969. Teaching English as a Second Language. New Delhi: tata McGraw-Hill Publishing Company

Hill, L.A. 1960. Picture Composition Book. London: Longman Group Ltd.

Lawrence, Marry S. 1983. Writing as a Thinking Process. Ann Arbor: Houghton Mifflin.

Pinontoan, Aaltje Tallei. 1984. "Pengaruh Bahasa Ibu dan Tingkat Pendidikan Orang Tua terhadap Kemampuan Mengarang. Tesis. Pascasarjana IKIP Jakarta 1999. Penelitian Tindakan Kelas. Manado: FPBS IKIP Manado

Sapani Ha Suardi, Mulyati Yeti, dan Idris Nunny Sulistiani. 1998. Teori Pembelajaran Bahasa. Jakarta: Departemen Pendidikan dan Kebudayaaan Sudjana. 1989. Metode Statistika. Bandung: Penerbit Tarsito Tallei. 1972/2004. Buku Latihan Mengarang (Jilid I). Manado: HR Studio

Tim Pelatih Proyek PGSM. 1999. Penelitian Tindakan Kelas. Jakarta: Departemen Pendidikan dan Kebudayaan RI. 